\title{
A PUBLICIDADE E OS SÍMBOLOS RACIAIS
}

As campanhas Benetton sempre causam polêmica. Uma delas, particularmente, provocou discussões aqui no Brasil, país com história escravocrata recente - a da foto que registra duas crianças: uma negra e uma branca. A especialista em questões étnicas, Solange M. Couceiro de Lima, analisa as peças publicitárias da marca no artigo a seguir.

Várias pesquisas efetuadas na intersecção Antropologia/ Sociologia e Comunicação têm focalizado as relações entre a população negra e a Comunicação Social. Entenda-se, aqui, como Comunicação Social tanto a mídia impressa, o rádio, a televisão, a propaganda, como também as artes (Cinema, Teatro, Música).

Representações veiculadas pela comunicação sobre esse segmento étnico, ou então o modo como os negros se profissionalizam na mídia, têm sido abordadas em artigos, livros ou teses acadêmicas.

Há também pesquisas sendo realizadas nesse campo.

Por interesse pessoal, trabalhando nessa área em pesquisas e teses, ministrando cursos e orientando estudos de pós-graduação, tenho acompanhado de perto as reflexões sobre esse tema.

Particularmente a área de publicidade tem-me despertado atenção, por ser um universo ainda pouco explorado academicamente $\mathrm{e}$, também, por ser um campo de certa e constante criatividade no modo de tratar determinados produtos ou assuntos.

\section{A AUTORA}

Solange Martins Couceiro de Lima

Professora Doutora de Antropologia da

Comunicação da ECA-USP, pesquisadora na área de grupos étnicos e Meios de Comunicação, autora de $\mathbf{O}$ Negro na televisão de São Paulo - Um Estudo de Relações Raciais, ed. FFCHL, (série Antropologia). 


\section{PREOCUPAÇÃO COM A UNIVERSALIZAÇÃO}

Uma das campanhas publicitárias mais interessantes surgida nesses últimos anos desse ponto de vista é, na minha opinião, a da marca Benetton baseada, como se sabe, no slogan "United Colors", como que propondo a união das raças através das cores.

Considerando o caráter multinacional da empresa, o sentido publicitário de tal campanha parece-me apontar para uma preocupação com a universalização.

Essa universalização revelase na utilização de modelos de diferentes origens raciais e étnicas, vestindo roupas coloridas, como que desejando abranger todas as cores raciais.

De repente, esse jogo multicolorido dá lugar a um jogo de contrastes entre o branco e o preto, envolvendo pessoas, roupas e objetos, como por exemplo a criança negra adormecida e envolta por ursos de pelúcia brancos sugerindo a leveza do algodão ou a brancura da neve.
Muitas vezes motivo de polêmica, parece-me que as mensagens emitidas têm como característica produzir discussão exatamente por permitirem leituras variadas de seus conteúdos.

É uma espécie de polissemia, uma mesma imagem permitindo várias interpretações num jogo pleno de ambigüidade.

Para exemplificar lembraria a imagem que unia por algemas a mão branca à negra. Essa mensagem poderia sugerir para alguns que o negro estaria sendo preso pelo branco, mas também poderia ser o contrário, ou quem sabe, estaria demonstrando a união fraterna das duas raças?

No mês de maio de 1990 (em comemoração ao Dia das Mães, ou seria ao Treze de Maio?) surgiu nos outdoors e revistas a majestosa figura de um seio negro amamentando uma criança branca. Imagem forte, plasticamente bela, polêmica. Foi debatida pela mídia e pelo movimento negro por evocar, como uma leitura possível, a ama de leite, obrigada a abandonar seus próprios filhos para amamentar $o$ filho do senhor de engenho. Em síntese, a clássica figura da mãe negra.
Num país de história escravocrata tão recente como o nosso, dificilmente se deixaria de interpretar tal imagem como a atualização do uso que a escravidão e o homem branco fizeram da mulher negra.

Há que se levar em conta sempre, como já disse, a situação histórica e social do país onde a mensagem é veiculada, que faz com que determinados signos se transformem em símbolos nem sempre tranqüilamente assimilados pela sociedade.

A mãe negra pode ser vista, neste caso, como símbolo da opressão com que a escravidão contemplou o segmento negro. Uma leitura possível.

\section{AMBIGÜIDADES}

Parece-me que o tom de campanha publicitária da marca em questão é lidar exatamente com essas ambigüidades,

é deixar aberta a possibilidade de leituras diferentes e até divergentes e tratar mesmo alguns temas com certo tom de irreverência

(o padre e a noviça cujo beijo abalou a Itália, mas foi 
bem absorvido neste imenso país católico).

Em seguida, um outro outdoor da marca Benetton: o contraste entre o branco e o negro era representado através de uma criança loira de rosto redondo e cachos no cabelo, abraçada a uma outra criança negra de belos olhos e cabelos penteados de modo a parecerem dois chifres no alto da cabeça. Figuras bem familiares à simbologia cristã: o anjinho barroco e o diabinho, um branco e outro negro. Não me pareceu que haveria possibilidade de segunda, terceira ou quarta leituras. A polissemia deu lugar, neste caso, a uma imagem unívoca: aquela que o imaginário popular, na tradição oral e folclórica, literária e mesmo pseudo-científica, associa o negro ao mal e o branco ao bem. Talvez o fato de a escolha de imagens ter recaído sobre duas crianças tenha como resultado provocar um efeito emocional mais forte.

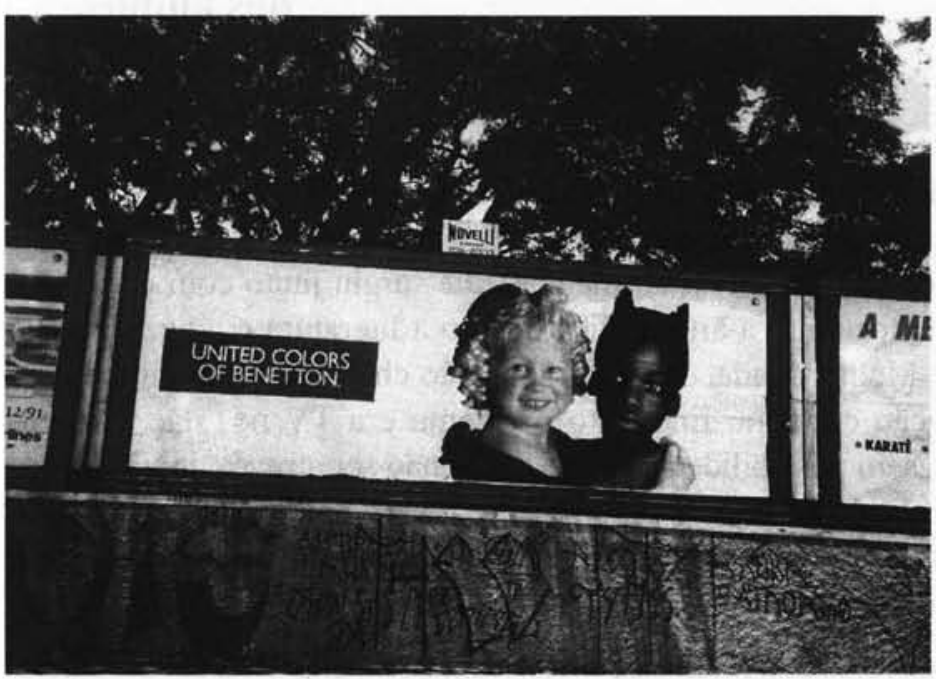

Como não ver naquela mensagem publicitária um conteúdo racista?

Como não ver nela, atualizada, toda a representação negativa que se constrói na sociedade brasileira sobre o negro e que, circulando por ela, é captada, reelaborada e devolvida pela mídia com grande eficiência?

Mais do que isto, como entender que aquela mensagem tivesse sido veiculada no país da democracia racial justamente na semana em que se comemorou o Dia da Consciência Negra o 20 de novembro - dia de Zumbi, o herói de um povo, que precisa ser urgentemente resgatado pela história, pela mídia e pela vida desse mesmo país.

Artigo publicado no Jornal da USP, na semana de 9 a 12 de dezembro de 1991, p. 2. 